Огляди літератури, оригінальні дослідження, погляд на проблему, короткі повідомлення, замітки з практики УДК 618.1-007.575.191

\title{
ГЕНЕТИЧНІ АСПЕКТИ ПРОЛАПСУ ВНУТРІШНІХ СТАТЕВИХ ОРГАНІВ У ЖІНОК
}

(С.П. Григоренко, О.Г. Шиманська, Н.І. Карпекіна

Вінницький національний медичний університет ім. М.І. Пирогова

РЕЗЮМЕ. Досліджено вплив генетичних чинників у жінок з пролапсом внутрішніх статевих органів. Виявлено, що генетичний вклад складає, за даними дерматогліфіки, 48,8 \%, генеалогії - 73,3 \% та цитогенетики - 24,0 \%. КЛЮчОВІ СЛОВА: пролапс матки, дерматогліфіка, генеалогія, цитогенетика.

Вступ. Пальцева дерматогліфіка є одним 3 інтегральних показників організму. Інформація про особливості генотипу індивідуума зберігається як у формі гребенястих візерунків, так і в їхній топографії на пальцях [1]. Значущість розподілу шкірних візерунків за типами залежить від структури хромосом, особливо статевих [2]

Закладка гребенястої шкіри починається в кінці першого триместру внутрішньоутробного розвитку плода, а диференціювання гонад закінчується до кінця 8-го тижня [3]. У Х-хромосомі містяться гени, які відповідальні за формування статі та утворення гребенястої шкіри $[4,5]$, обумовлює високу частоту дуг та петель і зменшення гребенястого ліку, а Ү-хромосома - високу частоту завитків та збільшення гребенястого ліку [6]. Спостерігається значний відсоток особливостей шкірного рельєфу в жінок з вадами розвитку сечостатевої системи хромосомного генезу [7], вадами розвитку піхви та матки [8] Ембріональні подушечки, під впливом яких утворюються шкірні візерунки, формуються 3 ектомезенхіми на ранньому етапі ембріонального розвитку з цілим рядом інших структур [9]. Збільшення або зменшення гребенястого ліку, дистальне зміщення осьового трирадіуса, редукція або відутність пальцевого трирадіуса С, на явність вираженої чотирипальцевої борозни, підвищена покресленість шкіри долонь властиві багатьом спадковим порушенням [6]. Геном кожної особи характеризується унікальною комбінацією поліморфних варіантів ділянок конститутивного або С-гетерохроматину за величиною та особливостями локалізації на хромосомах [10]

У патогенезі розвитку пролапсу геніталій у жінок молодого віку провідну роль відіграє системна дисплазія сполучної тканини, яка має прояви на рівні всіх органів і систем організму, а пролапс $€$ частковим її виявленням [11]

Мета дослідження. Визначити вклад генетичних чинників у формуванні пролапсу внутрішніх статевих органів у жінок з метою ранньої профілактики даної патології.

Матеріал і методи дослідження. Виконано дерматогліфічне, генеалогічне та цитоге- нетичне обстеження жінок віком 35-75 років 3 пролапсом внутрішніх статевих органів, яким проведено хірургічне лікування.

Контрольну групу склали фенотипово та соматичне здорові жінки з нормальною репродуктивною функцією. Відбиток рук (308 долонь та 1540 пальців) отримували за допомогою чорної друкарської фарби на білому папері з подальшим вивченням [5]. Дослідження візерунків шкіри проводили за методикою Cummis та Midid з використанням класифікації Генрі [6].

Вивчали 9 груп показників: 1) тип рисунка кінцевих фаланг пальців; 2) величина гребенястого ліку (пальцевий, долонний, загальний); 3) пальцеві трирадіуси; 4) осьові трирадіуси (наявність, зміщення, кут atd); 5) рисунок долонних подушечок (гіпотенар, тенар, I, II, III, IV); 6) закінчення долонних головних ліній А, В, C, B; 7) згинальні складки долоні (покресленість, поперечна чотирипальцева борозна та їі варіанти); 8) дельтоподібний індекс; 9) тотальний індекс головних ліній долоні. Усього вивчено 45 ознак.

Генеалогічний метод дослідження [12] використовували 3 дотриманням таких правил: родовід зображався так, що кожне покоління знаходилось на своїй горизонталі; сибси розташовувались у порядку народження зліва направо. Зображення ліній матері та батька включало міжнародну систему символів. Чоловіки родичок пробанда зображались нижче лінії родичок, якщо вони здорові та не впливали на виникнення даного захворювання, взагалі опускалися. Проведено вивчення родоводів у 35 жінок 3 пролапсом геніталій. Матеріалом для цитологічного дослідження були лімфоцити венозної крові 25 жінок 3 пролапсом внутрішніх статевих органів.

Стерильний забір крові й культивування клітин здійснювали відповідно до стандартної методики каріотипування (напівмікрометод). Клітини крові культивували 48-52 год при температурі $37{ }^{\circ} \mathrm{C}$ в середовищі PB max і 90 хв 3 кальцемідом (0,1 мкг/мл) для накопичення лімфоцитів на стадії метафази. Для кожної пацієнтки ставили декілька паралельних культур. 
Огляди літератури, ориеінальні дослідження, погляд на проблему, короткі повідомлення, замітки з практики

Промивали клітинний осад гіпотонічним розчином хлориду калію (0,55 \%) протягом 12 хв при температурі $37^{\circ} \mathrm{C}$. Потім проводили фіксацію (метанол і льодяна оцтова кислота - 3:1). Після висушування на повітрі препарати забарвлювались за методом Гімза [І3]. Барвник готували на стандартному Na-K фосфатному буфері $(\mathrm{pH} 6,8)$, термін забарвлювання склав 5 хв. Диференційоване забарвлення хромосом проводили за методом Cassperson з використанням 0,25 \% розчину трипсину [14].

Перегляд препаратів здійснювали за допомогою мікроскопів Aхіoscop 40 та Microstar IV, окуляр 10, об'єктив 20 і 100. Для хромосомного аналізу відбирали клітини на стадії метафази з повним хромосомним набором. Було переглянуто від 50 до 100 метафаз для кожної пацієнтки.

Результати досліджень обробляли за допомогою методів варіаційної статистики Вірогідність результатів оцінювали за допомогою t- критерію Стьюдента.

Результати й обговорення. Аналіз отриманих дерматогліфічних даних показав, що у жінок з пролапсом матки спостерігалося збільшення гребенястого ліку на пальцях лівої руки на 15,3 \% та правої руки - на 15,0 \% $(p<0,05)$. Збільшувався гребенястий лік ab, відповідно, на лівій руці на $12,5 \%$, на правій на $11,0 \%(p<0,05)$. Гребенястий лік сd на лівій та правій руках перебував на рівні контрольно групи ( $p>0,05)$.

Спостерігалось збільшення долонного ліку на лівій (на 10,1\%) та правій (на 10,4 \%) руках $(\mathrm{p}<0,05)$. Збільшувалися загальний пальцевий гребенястий лік (на 17,3 \%) та загальний гребенястий лік (на 13,2 \%). Відмічалось зменшення кута atd на лівій руці на 13,8 \%, на правій - на 10,3 \%. Тотальний індекс головних ліній зменшувався на 12,4 \% $(p<0,05)$. Додаткові осьов трирадіуси спостерігались на правій руці в $(1,85 \pm 1,83)$ \%. Рисунок на другій міжпальцевій подушечці лівої руки збільшувався на 99,0 \%, на правій - на 86,5 \% $(p<0,05)$. На третій міжпальцевій подушечці, навпаки, спостерігалось зменшення рисунка лівої руки на 58,0\%, на правій на 82,0\% $(p<0,05)$. Зменшення рисунка спостерігалось і на четвертій міжпальцевій подушечці лівої (на 59,5\%) та правої (на $84,2 \%$ ) рук. Також відбувалось зниження рисунка на гіпотенарі на лівій (на 33,2 \%) та правій (на 57,7 \%) руках $(\mathrm{p}<0,05)$. Спостерігалась підвищена покресленість долонь на $37,0 \%(p<0,05)$.

Із 45 дерматогліфічних ознак у жінок з пролапсом матки достовірна значимість мала місце у 48,8 \% (22 ознаки), це проявилося збільшенням гребенястого пальцевого та долонного ліку, візерунку на другій міжпальцевій подушечці, підвищеною покресленістю долонь. Спостерігалось зменшення кута atd, тотального індексу головних ліній, знижувався рисунок на третій, четвертій міжпальцевих подушечках та гіпотенарі.

Аналіз родоводів у жінок з пролапсом геніталій показав, що у 15 жінок (42,9 \%) виявлена спадкова схильність до даного захворювання (тобто в родоводі згадується про опущення чи повне випадання матки в однієї або декількох родичок). В 10 випадках із $15(66,7 \%)$ в сім'ях, окрім пробанда, був 1 випадок захворювання. у 5 випадках (33,3 \%) мало місце випадіння матки у 2 і більше членів родини, тобто відмічалась чітка тенденція до збільшення ризику.

Серед родичів першого ступеня спорідненості пролапс геніталій зустрічався у 12 випадках (80,0 \%), а саме: у матері пробанда - 11 випадків (73,3 \%), у сибсів - 6 випадків (40,0 \%) Серед родичів другого ступеня спорідненості дана патологія мала місце у 2 жінок (13,3\%). В 1 випадку $(6,7$ \%) спостерігали збільшення ризику серед родичів як першого, так і другого ступеня спорідненості.

В 11 випадках (73,3 \%) мало місце збільшення ризику даної патології лише у родичів по материнській лінії. В 1 випадку успадкування пролапсу геніталій спостерігалось по батьківській лінії (6,7 \%). У 3 випадках (20,0\%) випадання матки, окрім пробанда, мали лише сибси, тому визначити, по якій лінії успадковане дане захворювання, неможливо.

Таким чином, наявність пролапсу геніталій у родичів першого ступеня спорідненості в кожному третьому випадку, а також збільшення ризику захворювання в основному по материнській лінії (73,3 \%) додатково свідчать про високий рівень спадкової схильності до даної патології (рис.1).

При анкетуванні даної групи жінок ми намагались виявити, окрім спадкового фактора, ще й інші чинники, які б могли вплинути на виникнення пролапсу геніталій, зокрема кількість пологів, масу плода при народженні, травми зовнішніх статевих органів при пологах, наявність медабортів, запальних захворювань внутрішніх статевих органів, фізичні навантаження.

3 анамнезу відомо, що одні пологи мали місце у 5 жінок (14,3\%), двічі народжували 20 жінок $(57,1 \%)$, тричі й більше разів - 9 жінок $(25,7 \%)$, а в одному випадку $(2,9 \%)$ були кесарів розтин та одні пологи. 23 жінки $(65,7 \%)$ вказують на травми зовнішніх статевих органів і шийки матки при пологах. Маса новонароджених склала: до 3500,0 - 34; 3501,0-4000,0 - 46; 4001,0-5000,0 - 9, більше 5000,0 - 4. 
Огляди літератури, ориеінальні дослідження, погляд на проблему, короткі повідомлення, замітки з практики I
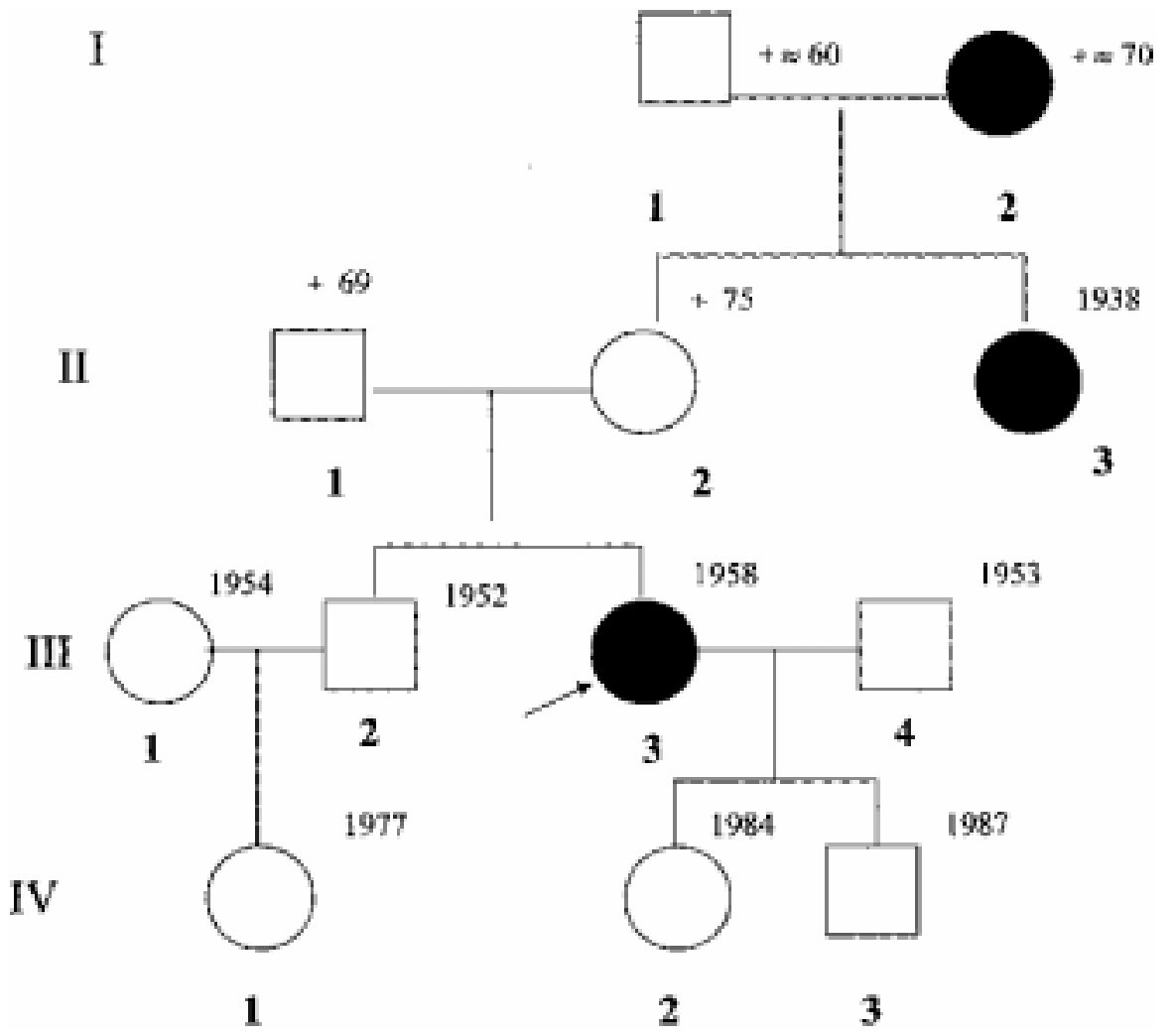

Рис. 1 Родовід пацієнтки Б., 48 р., з пролапсом геніталій III ступеня .

I (1) - помер у віці приблизно 60 років, страждав від алкоголізму, причина смерті невідома.

I (2) - померла у віці приблизно 70 років, мала випадання матки.

I (1) - хворів на IXC, помер у віці 69 років після перенесеного інфаркту

міокарда

II (2) - померла у віці 75 років від раку легень.

I (3) - має випадання матки, оперована.

III (2) - хворіє на IXC

III (3) - пробанд, має повне випадання матки.

На 1 медаборт в анамнезі вказують 5 жінок (14,3\%), на 2 і більше -21 пацієнтка $(60,0 \%)$. Викидні мали 4 жінки (11,4\%). Запальні захворювання органів жіночої статевої сфери перенесли 7 (20,0 \%) жінок. На значне фізичне навантаження протягом життя вказували 26 (74,3%) жінок.

Аналіз хромосомної патології у жінок з пролапсом внутрішніх статевих органів представлено в таблиці 1.

Із таблиці видно, що в 6 випадках (24,0 \%) виявлена патологія, яка являла собою варіанти хромосомного поліморфізму - значна міжхро-

Таблиця 1. Характеристика патологічних каріотипів у жінок з пролапсом внутрішніх статевих органів

\begin{tabular}{|c|c|c|}
\hline$№$ п/п & Каріотипи & Частота спостереження, \% \\
\hline 1 & $46, \mathrm{XX}, 1 \mathrm{qh}+13 \mathrm{pstk}(\Pi=1)$ & 4,0 \\
\hline 2 & $46, \mathrm{XX}, 1 \mathrm{qh}+(\Pi=2)$ & 8,0 \\
\hline 3 & $46, \mathrm{XX}, 16 \mathrm{qh}+(\Pi=2)$ & 8,0 \\
\hline 4 & $46, \mathrm{XX}, 9 \mathrm{qh}+(\Pi=1)$ & 4,0 \\
\hline 5 & $46, \mathrm{XX}, 15 \mathrm{pstk}(\Pi=1)$ & 4,0 \\
\hline 6 & $46, \mathrm{XX}, 21 \mathrm{pstk}(\Pi=1)$ & 4,0 \\
\hline 7 & $46, \mathrm{XX}, 22 \mathrm{pstk}(\Pi=1)$ & 4,0 \\
\hline
\end{tabular}


Огляди літератури, оригінальні дослідження, погляд на проблему, короткі повідомлення, замітки з практики мосомна та міжіндивідуальна варіабельність у 13, 15, 21 та 22 хромосомах. Основні морфоділянок конститутивного гетерохроматину $(Г X)$. логічні особливості цих хромосом - подовження Збільшення ГХ у довгому плечі хромосоми 1 супутніх ниток на коротких плечах цих хромосом, відмічалось в 3 випадках, у довгому плечі 16 каріотипи: 46,XX, 15 pstk; 46,XX, 21 pstk; 46,XX, 22 хромосоми - в 2 випадках та в довгому плечі 9 pstk; 46,XX, 1qh+, 13 pstk. хромосоми - в одному випадку.

Каріотипи даних індивідуумів такі: 46,XX 1qh+13pstk; 46,XX, 1qh+; 46,XX, 15 pstk та 46,XX, 9 qh+. Відомим $€$ феномен гетерохроматизації, при якому активність структури генів, розташованих близько до ГХ ділянки, репресується.

Видозміни акроцентричних хромосом, які на даний час є предметом дискусії, спостерігались

Вважається, що хромосомний поліморфізм - це варіант мінливості, мутації, при якій хромосоми можуть бути як нормальними, так і патологічними [15].

Результати дослідження частоти хромосомних аберацій у жінок з пролапсом матки представлено в таблиці 2, з якої видно, що у жінок репродуктивного віку (до 45 років) частота стаб-

Таблиця 2. Частота хромосомних аберацій у жінок з пролапсом внутрішніх статевих органів різних вікових груп (\%)

\begin{tabular}{|c|c|c|c|c|}
\hline Вік (роки) & $\begin{array}{c}\text { Кількість } \\
\text { хворих (п) }\end{array}$ & $\begin{array}{c}\text { Частота } \\
\text { стабільних } \\
\text { хромосомних } \\
\text { аберацій }\end{array}$ & $\begin{array}{c}\text { Частота } \\
\text { нестабільних } \\
\text { хромосомних } \\
\text { аберацій }\end{array}$ & $\begin{array}{c}\text { Частота } \\
\text { анеуплоїдій }\end{array}$ \\
\hline До 45 & 4 & 0,5 & 2,0 & 2,75 \\
\hline $46-50$ & 3 & 0,66 & 2,33 & 2,43 \\
\hline $51-76$ & 18 & 1,78 & 3,14 & 4,64 \\
\hline
\end{tabular}

ільних хромосомних аберацій склала 0,5\%, нестабільних - 2,0 \%, анеуплоїдії - 2,75\%. У жінок пременопаузального віку (46-50 років), - 0,66 2,33, 2,43 \% відповідно, тобто на рівні жінок репродуктивного віку. В жінок постменопаузального віку (51-76 років) частота стабільних хромосомних аберацій зросла на 72,0 \% (з 0,5 до 1,78 \%), нестабільних хромосомних аберацій - на $36,3 \%$ (з 2,0 до 3,14 \%), анеуплоїдії - на 47,6 \% (з 2,43 до 4,64\%).

При дослідженні цитогенетичних, мутаційних та молекулярно-генетичних порушень у більшості випадків було встановлено, що їх частота збільшується з віком. Структурні абераціі хромосом відносять до того типу генетичних порушень, які впливають на багатофакторний процес старіння. Порівняно $з$ дітьми частота стабільних аберацій у людей віком 50 років зростає в 10-15 разів [16].

Висновки. 1. У жінок з пролапсом внутрішніх статевих органів за дерматогліфічними ознаками $(48,8 \%)$ спостерігаються підвищення гре-

\section{ЛІТЕРАТУРА}

1. Катілов О.В. Особливості пальцевої дерматогліфіки у підлітків, притягнутих до кримінальної відповідальності // ПАГ. - 2004. - № 4. - С. 33-37.

2. Роль генетичних факторів при патології молочних залоз / П.М. Веропотвелян, В.М. Круподар та ін. // ПАГ. - 2004. - №2. - С. 95-100.

3. Гусєва И.С. Морфогенез и генетика гребешко- бенястого пальцевого та долонного ліку, покресленості долонь, зменшення кута atd, тотального індексу головних ліній, зниження рисунка на третій, четвертій міжпальцевих подушечках та гіпотенарі.

2. Спадкова схильність пролапсу спостерігається по материнській лінії (73,3 \%) з полігенно-мультифакторним типом успадкування.

3. У жінок з пролапсом матки спостерігаються варіанти хромосомного поліморфізму в 24,0 \%, частота хромосомних аберацій різко підвищується в постменопаузальному віці, стабільні аберації зростають на 72,0 \%, нестабільні - на $36,3 \%$, анеуплодії - на 47,6 \%. Тобто хромосомні аберації мають більший зв'язок з віком жінки, ніж $з$ даною патологією.

Перспективи подальших досліджень. Використання високоінформативних генетичних методів дослідження у першовагітних жінок дає можливість прогнозувати пролапс внутрішніх статевих органів. Раціональним методом розродження даної групи жінок $є$ кесарів розтин.

вой кожи человека. - Минск, 1986.- 200 с.

4. Войтенко В.П., Полюхов А.М., Колодченко В.П. О наследовании пальцевых узоров человека // Генетика. - 1979. - № 7. - С. 1317-1326.

5. Гладкова Т.Д. Кожне узоры кисти и стопы обезьян и человека. - М.: Наука, 1966.- 151 с.

6. Трепаков Е.А. Дерматоглифические исследо- 
Оеляди літератури, оригінальні дослідження, погляд на проблему, короткі повідомлення, замітки з практики вания в акушерско-гинекологической практике // Т.Н. Сенчакова // Акуш. и гин. - 2001. - № 3. - С. 39-43. Акуш. и гин. - 1976. - № 12. - С. 65-68.

7. Кирилова Е.А., Курбанова А.Г., Трепаков Е.А. Клинико-генетические исследования при пороках развития мочеполовой системы у женщин // Акуш. и гин. - 1973 - № 5 - C 41-43

8. Кривич И.П. Особенности дерматоглифических показателей у девочек и девушек с гиперандрогенией неясного генеза // Акуш. и гин. - 1987. - № 9. - C. 57-58.

9. Особенности дерматоглифики при внутриутробной гипотрофии / Е.В. Неудахин, С.В. Лукянова Н.А. Борисова, В.Г. Солониченко // Вопр. акуш. и перинат. медицины. - 1992. - № 2-3. - С. 33-34.

10. Акопян Г.Р. Деконденсація конструктивного гетерохроматину як вірогідна причина формування генокопій С-поліморфних варіантів хромосом // ПАГ. - 2005. - № 6. - С. 37-43.

11. Некоторые аспекты патогенеза пролапса гениталий / С.Н. Буянова, С.В. Савельев, В.П. Грипин Клико-гениалогический метод. в медицинской генетике. - Новосибирск: Наука, 1983. - 102 с.

13. Кулешов Н.П. Современньїе проблеми клинической цитогенетики. - М., 1991. - 164 с.

14. Caspersson T., Lomkka G. Lech J. 24 fluorescence patterns of human metaphase chromosome hereditas. 1971. - V. 67. - P. 89-102

15. Цитогенетический метод в диагностике репродуктивных потерь / О.Н. Андрушенко, В.Т.Германов, Е.В. Сорокина, О.С. Кузюбердина // Зб. наукових праць, вип. 13. - Київ - Луганськ, 2006. - С. 197-205.

16. Возрастная зависимость частоты хромосомных аберраций, определяемых методом FJSH в лимфоцитах здоровых доноров и лиц, подвергшихся неконтролируемому облучению в мал Воробцова, Н.М. Тимофеева, А.Н. Богомазова, А.В. Семенов // Успехи геронтологии. - 2003. - № 4. - С. 125-129.

\section{GENETIC ASPECTS AT WOMEN WITH PELVIC ORGAN PROLAPSE}

๑A.P. Hryhorenko, O.H. Shymanska, N.I. Karpekina

Vinnytsia National Medical University by M. Pyrohov

SUMMARY. The influence of genetic factors at the women with pelvic organ prolapse has been investigated. It has been established that the genetic part consists by the data of dermatoglyphics - $48,8 \%$, genealogy - $73,3 \%$ and cytogenetics $-24,0 \%$.

KEY WORDS: pelvic organ prolapse, dermatoglyphics, gen

Удк: 618.3-06:616.147-007.64]:618.14+618.34/.36]-005-07

\section{ОСОБЛИВОСТІ КРОВОТОКУ СИСТЕМИ „МАТИ-ПЛАЦЕНТА-ПЛІД” У ВАГІТНИХ З ВАРИКОЗНОЮ ХВОРОБОЮ ЗАЛЕЖНО ВІД ТЕРМІНУ ПОЯВИ Ї̈ СИМПТОМІВ}

СА.В. Жарких, В.Г. Сюсюка, Д.Є. Барковський, К.Ю. Нерянов, С.П. Онопченко Запорізький державний медичний університет

РЕЗЮМЕ. В результаті проведеного доплерометричного дослідження у вагітних з варикозною хворобою виявлені гемодинамічні порушення матково-плацентарного та плодово-плацентарного кровообігу. Такі зміни мали більш виражений характер у жінок, симптоми варикозної хвороби у яких виникли під час теперішньої вагітності. Вищезазначені зміни обумовлені зниженням діастолічного компонента кровотоку та є наслідком підвищення судинного опору у системі „мати-плацента-плід”.

КЛЮчОВІ СЛОВА: вагітність, варикозна хвороба, доплерометрія.

Вступ. Варикозна хвороба являє собою захворювання усієї судинної системи, що має різноманітні клінічні прояви та часто сприяє ускладненому перебігу гестації [2]. Високий ризик виникнення акушерських і перинатальних ускладнень передусім пов'язаний з варикозною хворобою (BX), коли мають місце більш виражені зміни кровопостачання органів репродуктивної системи [3]. Наявність екстрагенітальних захворювань та ускладнень вагітності, що можуть бути обумовлені нею, часто спричиняється до змін у плаценті, тим самим порушуючи її функцію з негативним впливом на стан утробного плода. Гемодинамічні процеси у системі „мати-плацента-плід” є одним 3 провідних чинників, які забезпечують фізіологічний перебіг вагітності, ріст та розвиток плода [4]

Мета дослідження. Вивчити стан матково-плацентарної та плодово-плацентарної гемодинаміки у вагітних з варикозною хворобою і залежно від терміну появи їі симптомів. 